\title{
EKSPRESI IDENTITAS MELALUI RELASI AYAH DAN ANAK PADA IKLAN YOUTUBE GRAB OFFICIAL
}

\author{
Yohanes Probo Dwi Sasongko() dan Rustono Farady Marta ${ }^{2)}$ \\ 1) IImu Komunikasi, Universitas Bunda Mulia \\ 2) Magister IImu Komunikasi, Universitas Bunda Mulia \\ Disetujui 12 September 2018
}

\begin{abstract}
In each interaction between humans, messages and communication content have a significant impact on the audience. Likewise with the presence of advertisement as a message delivery medium that is packaged as well as possible between ad creators as communicators to the communicants. The fundamental orientation of this research is to explore Grab Official Ads uploaded on Youtube since November 2017, entitled "“Luangkan Waktu Untuknya yang Selalu Ada Untukmu!" (Take Time for Him Who Is Always There for You!) through the Cultural Dimensions Theory which was found by Hofstede. Grab attended to reveal the phenomenon of online transportation which kept a little pro-contra story in the society, but this mode of transporting people was increasingly popular because it was able to answer the need for high mobility. This study finds the dynamics of the cultural dimensions through appreciation of Grab for its customers by an advertisement that express Indonesian identity through the relationship between father and son in four of the six dimensions. The remaining two dimensions are consistently found in most pieces of the ads scenes, the interpretation of the researcher is inline with Hofstede Insight's principle for the majority percentages of Indonesian cultural dimensions.
\end{abstract}

Keywords: Expression of Identity, Relationship, Youtube, Grab Official

\begin{abstract}
ABSTRAK
Dalam setiap kegiatan interaksi yang dilakukan manusia, pesan dan muatan komunikasi membawa dampak yang signifikan terhadap khalayak. Demikian pula dengan hadirnya iklan sebagai medium penghantar pesan yang dikemas sebaik mungkin antar kreator iklan sebagai komunikator kepada para komunikannya. Orientasi mendasar dari penelitian ini hendak menelusuri Iklan Grab Official yang diunggah pada Youtube sejak Bulan November 2017 yang bertajuk "Luangkan Waktu Untuknya yang Selalu Ada Untukmu!" melalui Teori Dimensi Budaya yang dicetuskan oleh Hofstede. Grab hadir menyibak fenomena transportasi online yang menyimpan sekelumit cerita pro-kontra di masyarakat, namun moda pengangkut orang ini justru kian digemari karena mampu menjawab kebutuhan akan tingginya mobilitas sehari-hari. Penelitian ini menemukan dinamika dimensi budaya melalui apresiasi Grab bagi para pelanggannya dalam iklan yang mengekspresikan identitas Indonesia melalui relasi diadik antara Ayah dan anaknya tersebut pada empat dari enam dimensi. Dua dimensi tersisa secara konsisten ditemukan pada sebagian besar potongan gambar adegan iklan, interpretasi peneliti ini sejalan dengan prinsip Hofstede Insight untuk mayoritas prosentase dimensi budaya Negara Indonesia.
\end{abstract}

Kata Kunci: Ekspresi Identitas, Relasi, Youtube, Grab Official

\footnotetext{
*Korespondensi Penulis:

E-mail: yprobo@bundamulia.ac.id
} 


\section{PENDAHULUAN}

Berbagai upaya dan beraneka ragam tindakan yang dapat ditempuh dalam rangka memperkenalkan sebuah produk yang dihasilkan oleh instansi, perusahaan atau lembaga tertentu. Salah satu tindakan yang kerap kita lihat, dengar, dan perhatikan melalui upaya tersebut tidak lebih dari sekedar berupa sosialisasi atau kegiatan promosi di pelbagai saluran media. Baik itu melalui media cetak, digital maupun elektronik. Berbagai aktivitas tersebut dilakukan untuk memperoleh hal yang ditargetkan di dalam pelaksanaan kegiatan industri tersebut.

Bercermin pada tataran definitif sebelumnya, maka dalam menjalankan kegiatan usaha dalam berbagai bentuk sebuah usaha yang dijalankan harus memiliki orientasi yang jelas. Dengan kata lain, ketika kita mengagendakan kegiatan yang dilakukan sebagai usaha dengan tujuan mencari keuntungan, maka bisnis tersebut harus dirancang sedemikian rupa sehingga membawa efek positif yang diharapkan.

Mempromosikan produk dalam tayangan media tertentu merupakan bagian dari upaya pemasaran yang signifikan dampaknya, Putra (2017:9) mengungkapkan pula peran iklan dan kesadaran khalayak pada merek tertentu terhadap minat beli konsumen. Hal ini juga dipengaruhi oleh kepiawaian sosok insan kreator iklan dalam mengemas tindakan promosi tersebut sebagai fase yang harus dipahami secara seksama. Promosi produk melalui media televisi sebagai perantara, tentu berbeda dengan cara produser mempromosikan produk bisnis melalui media cetak atau koran atau bahkan melalui media internet yang menuntut adanya interaktifitas (Hariningsih, 2013:13). Semuanya tentu berbeda dan memiliki kelebihan dan kekurangan masing-masing.

Keberhasilan pencapaian target dan kesuksesan sebuah perusahaan dalam melakukan promosi, tidak akan lepas dari faktor-faktor yang menyertainya. Faktorfaktor tersebut, antara lain: sumber daya manusia, visi dan misi perusahaan, hubungan relasi dengan lingkungan sekitar dan sebagainya. Ujung tombak dari kesuksesan suatu perusahaan adalah memajukan merek produk maupun perusahaan sebagai pemikat konsumen, ditunjang dengan efektifitas iklan yang memediasi daya tariknya (Kartika, 2016:193-198).

Iklan dapat dicerna dengan baik, sebagai media promosi. Sebuah mekanisme kerja yang efektif dalam memasarkan berbagai produk kepada konsumen. Melalui iklan pula, masyarakat atau khalayak umum dapat mengenal, mengetahui, menerima dan mengambil jarak terhadap produk tersebut. Dapat dipahami pula, iklan merupakan media penyampaian pesan melalui informasi yang dimiliki oleh perusahaan untuk dikomodifikasikan dan komunikasikan, antara produsen ke konsumen.

Posisi iklan sebagai media komunikasi persuasi dirancang sedemikian rupa sesuai karakter media, segmentasi khalayak sasarannya dan kebutuhan sesuai tujuan pemrakarsanya. Menurut Widiantoro (2015:159) jika dikategorikan berdasarkan kepentingannya, maka iklan tidak hanya bersifat komersial saja. Iklan juga dapat mengedepankan kepentingan non komersial yang bertujuan sosial sepenuhnya atau semi komersial. Bentuk iklan ini dikenal dengan istilah Iklan Layanan Masyarakat atau disingkat ILM dan dalam Bahasa Inggris lebih populer dengan sebutan Public Service Advertising (Singh \& Singh, 2017:53) yang tidak jarang disingkat menjadi Public Service Ads (Chang \& Chang, 2014:421) atau sebagian menyebutnya sebagai Public Service Announcement (Manickavelan, 2013:26). Iklan tersebut lebih menekankan kepentingan umum yang berupaya menanamkan kesadaran dan pengetahuan yang mendalam kepada masyarakat, tentang pelbagai isu, dan fenomena sosial yang tengah hangat dibicarakan masyarakat. (Chritian, 2017:157)

Di Indonesia tidak ada organisasi khusus yang dibentuk untuk menangani 
iklan layanan masyarakat atau ILM. Pada umumnya ILM dibuat secara sendiri-sendiri oleh biro iklan yang bekerja sama dengan media dan pengiklan. Hal ini mengakibatkan kurangnya komitmen dan sinergi dalam merumuskan iklan, biaya, serta pesan yang ingin disampaikan sehingga ILM tidak dilakukan secara rutin. Selain itu ILM juga dikenakan pajak iklan, walaupun ruang dan waktunya disumbangkan oleh media. (Putra, 2017:61)

Pemasaran produk lewat iklan pada jaman sekarang ditempuh melalui berbagai upaya guna menghadapi persaingan, sehingga kreatifitas iklan dituntut semakin mampu mengakomodir respon khalayak luas dan menimbulkan persepsi positif. Hal ini yang menjadi perhatian salah satu penyedia jasa transportasi berbasis online dengan merek Grab, terutama dalam meluncurkan iklan komersilnya. Berkaca dari pengalaman sebelumnya, perusahaan yang memiliki aneka ragam moda transportasi pilihan tersebut memperoleh kecaman di berbagai media sosial atas iklan \#pilihaman Grab Bike Indonesia. Vita Aditya dan Lisdian Fitri Nasrianti (2017:2) menguraikan bahwa video berdurasi 45 menit yang diunggah pada Hari Minggu, 18 September 2016 oleh Grab Indonesia, terkesan memojokkan ojek pangkalan melalui jalan cerita yang mengetengahkan remaja bernama Dinda mengalami kecelakaan berakibat luka parah dan berdarah. Bukan saja menuai protes di dunia maya, terlebih penolakan terjadi secara masif bahkan dalam bentuk larangan operasional.

Kepala Dinas Perhubungan (Kadishub) Siantar menyampaikan bahwa kehadiran Go-Jek dan Grab menuai pro kontra di masyarakat. Beragam tanggapan muncul untuk menyangkal fakta di lapangan, bahwa kini semakin banyak masyarakat menggunakan jasa angkutan berbasis digital atau aplikasi ini. Di satu sisi, kehadirannya menimbulkan penurunan pendapatan bagi penyedia jasa konvesional seperti angkutan umum dan becak. Kondisi pro kontra transportasi online ini, bukan hanya terjadi di kota bermotto "sapangambei manoktok hitei" ini. Tapi sudah terjadi di kota-kota lain. Solusi penyelesaian pro kontra pun belum maksimal, baik oleh pemerintah pusat maupun daerah. Harapannya, antara penyedia jasa digital dan konvesional jangan terjadi gesekan. Menjamurnya angkutan berbasis aplikasi daring dinilai berdampak negatif bagi usaha angkutan darat seperti taksi, angkutan kota, dan angkutan pedesaan. Sekretaris Jenderal Dewan Pimpinan Pusat (DPP) Organisasi Pengusaha Angkutan Darat (Organda), Ateng Aryono, mengatakan kehadiran transportasi membuat jumlah usaha angkutan transportasi konvensional semakin menyusut dan kini mulai sepi pelanggan, bahkan secara nasional sebenarnya Indonesia mengalami kerugian potensi pajak hingga sebesar 16 triliun. (https://www.republika.co.id/berita/ekonom i/keuangan/17/08/02/ou2dir361-organdaindonesia-kehilangan-potensi-pajak-rp-16triliun? source $=$ graboards.com) .

Menghadapi situasi krisis tersebut, justru disikapi secara optimis oleh berbagai penyedia layanan transportasi online di Tanah Air. Berdasarkan artikel yang ditulis Leksono (2017:382) hasil penilaian Top Brand 2016 Fase kedua untuk kategori transportasi online, merek Go-Jek berhasil meraih 80,8\%, sementara Grab hanya sanggup bertengger di posisi kedua dengan capaian $14,7 \%$, disusul Uber dengan $1,7 \%$ dan Blu-Jek mengekor di angka $0,7 \%$. Kini upaya manajemen Grab terus berbenah kian menampilkan inovasinya, pada Bulan November 2017 Grab Official meluncurkan iklan bertajuk "Luangkan Waktu Untuknya yang Selalu Ada Untukmu!". Dalam laman resminya, peluncuran iklan ini sekaligus ingin dimaknai sebagai penanda perjalanan selama lima tahun perusahaan ini hadir bagi masyarakat di Indonesia. Grab tidak hanya menyediakan upaya untuk menghubungkan orang dari titik penjemputan menuju ke tujuannya, namun lebih kepada peran mendekatkan pada orang yang dianggap paling berarti bagi setiap penggunanya. Oleh karenanya iklan ini diiringi dengan kampanye \#DekatDenganGrab di 100 kota 
layanan, semakin menjangkau luas dari pulau Sumatera hingga ke Papua. Hal ini mengukuhkan jaringan yang telah dibangun kokoh pada tujuh negara di Asia Tenggara, karena Grab mengakui pentingnya face to face connection sehingga kedekatan pengguna dengan orang-orang yang dikasihinya patut diapresiasi. (https://www.grab.com/id/blog/luangkanwaktu-untuknya-yang-selalu-ada-untukmu/) Pemilihan iklan ini menarik untuk dianalisis tidak saja dari aspek promosinya, melainkan dapat ditelisik berbagai dimensi budaya. Berbagai dimensi budaya tersebut dikategorikan sebagai bagian-bagian yang diharapkan oleh kreator iklan mampu menghadirkan persepsi baru ke benak khalayak.

\section{LANDASAN TEORI}

Dalam rangka menelaah lebih jauh terkait dimensi budaya dalam iklan Grab "Luangkan Waktu Untuknya yang Selalu Ada Untukmu!", maka sebagai tinjauan untuk melihat lebih dalam lagi. Penulis akan menganalisa iklan tersebut dari kajian teori Hofstede mengenai budaya yang tengah terjadi saat ini. Hofstede (1980) mendefinisikan budaya merupakan suatu pemrograman kolektif dari pikiran yang membedakan anggota suatu kelompok atau kategori orang, dari yang lain. Hofstede menganalisis budaya dari beberapa bangsa dan mengelompokkannya ke dalam beberapa dimensi. Selanjutnya, Hofstede kembali menegaskan dimensi budaya "Dimension of culture is The comparison of cultures presupposes that there is something to be compared - that each culture is not so unique that any parallel with another culture is meaningless"

Dalam pemahaman ini, Hofstede memaknai bahwa setiap budaya memiliki kekhasan masing-masing. Setiap budaya mencirikan sebuah identitas budaya itu sendiri, dan melibatkan semua aspek yang ada di dalamnya. Budaya juga diidentikan dengan komunikasi, artinya kedua hubungan tersebut saling kait mengkait (Hofstede, 1994).

Pengertian di atas dapat dipahami bahwa perbandingan budaya mengandaikan bahwa ada sesuatu yang harus dibandingkan - bahwa setiap budaya sebenarnya tidaklah begitu unik, bahwa setiap budaya yang paralel dengan kebudayaan lain tidak memiliki makna yang begitu berarti. Berikut ini adalah enam dimensi budaya yang dibangun oleh Hofstede dan beberapa peneliti lain:

1. Power Distance, terkait kepada solusisolusi yang berbeda terhadap masalah dasar dari ketidak setaraan manusia;

2. Uncertainty Avoidance, terkait dengan tingkat dari stres dalam lingkungan sosial menghadapi masa depan yang tidak diketahui;

3. Individualism versus Collectivism, terkait dengan integrasi dari individu ke dalam kelompok-kelompok utama;

4. Masculinity versus Feminimity, terkait dengan pembagian dari peran emosi antara wanita dan laki-laki;

5. Long Term versus Short Term Orientation, terkait kepada pilihan dari fokus untuk usaha manusia: masa depan, saat ini, atau masa lalu;

6. Indulgence versus Restraint, terkait kepada gratifikasi dibandingkan kendali dari kebutuhan dasar manusia untuk menikmati hidup.

\section{Perspektif Metodologis}

Pada bagian ini, akan dijelaskan mengenai metode penulisan. Penulisan ini menggunakan metode kualitatif. Dengan mengacu perspektif Judith Martin dan Thomas Nakayama dalam kajiannya mengenai lintas kultural dalam dinamikadinamika kemajemukan budaya yang ada. Oleh karena itu, yang dimaksud dengan kompetensi antar budaya adalah kompetensi yang dimiliki oleh seseorang (baik secara pribadi, berkelompok, organisasi, atau dalam etnik dan ras) untuk meningkatkan kapasitas, ketrampilan, pengetahuan yang berkaitan dengan kebutuhan utama dari orang-orang lain yang berbeda kebudayaannya. Kompetensi antarbudaya 
merupakan suatu perilaku yang kongruen, sikap, struktur, juga kebijakan yang datang bersamaan atau menghasilkan kerja sama dalam situasi antarbudaya.

Setiap kompetensi antarbudaya dari seorang individu tergantung pada institusi sosial, organisasi, kelompok kerja, dan tempat individu berada (secara fisik maupun sosial). Semua faktor itu membentuk sebuah sistem yang memengaruhi kompetensi antarbudaya yang efektif. Jadi secara makro dapat dikatakan bahwa kompetensi antarbudaya merupakan tanggung jawab atas total system sebuah kebudayaan.

Ada beberapa faktor yang mendorong kita mempelajari kompetensi antarbudaya, yaitu adanya perbedaan nilai antarbudaya; tata aturan budaya cenderung mengatur dirinya sendiri; kesadaran untuk mengelola dinamika perbedaan; pengetahuan kebudayaan yang sudah institusionalisasi; kemudian mengadaptasikan kekuatan semangat layanan dalam keragaman budaya demi melayani orang lain.

Menganalisa kajian lintas kultural secara komprehensif, maka penulis akan menganalisa kajian ini dengan salah satu paradigma. Ada tiga perspektif paradigma yang kontemporer untuk ditelaah bersama, antara lain: (a) Perspektif fungsionalis (b) Perspektif intepretif dan (c) Perspektif Kritis. Dalam perspektif fungsionalis, salah satu aspek yang dapat dikaji secara mendalam dan menyeluruh, adalah bagaimana persepsi atau pandangan orang atau individu terhadap iklan yang dilihatnya tersebut. Ditekankan bahwa konsep individu mengarah pada tindakan melihat konten secara lebih luas. Konsep yang menekankan bahwa identitas tersebut dibentuk sebagian oleh diri dan sebagian lagi dalam hubungannya dengan anggota kelompok. Berdasarkan perspektif ini, diri sendiri mengambil ruang untuk membentuk pemahaman dan pengenalan terhadap dirinya dan pengetahuan terhadap budaya yang ada disekitarnya. Oleh karena itulah, bagaimana kita memahami diri sangat bergantung pada latar belakang budaya.
Dalam Perspektif fungsionalis, misalnya terkait lintas budaya. Budaya Amerika selalu menekankan pada generasi mudanya untuk mengembangkan rasa yang kuat akan identitas, untuk mengetahui siapa diri mereka, menjadi mandiri dan bergantung pada diri sendiri. Hal ini mencerminkan sebuah penekanan pada nilai budaya individualisme. Akan tetapi, hal ini tentu saja tidak terjadi di negara lain. Psikolog lintas budaya Alan Roland (1988) telah mengidentifikasikan tiga aspek universal dari identitas yang ada di dalam semua individu: (1) identitas individu, rasa independen 'aku' yang berbeda dengan yang lain; (2) identitas keluarga, hadir dalam budaya kolektif, menekankan pada pentingnya kedekatan dan ketergantungan emosional satu sama lain; (3) identitas spiritual, kenyataan spiritual dalam diri manusia secara keseluruhan .

Perspektif interpretif, dibangun di atas gagasan-gagasan tentang pembentukan identitas dalam pengertian yang lebih dinamis. Perspektif ini menekankan bahwa identitas dinegosiasikan, dibentuk, dikuatkan, dan ditantang melalui komunikasi dengan orang lain; mereka muncul ketika pesan-pesan dikomunikasikan (Hecht, Collier, \& Ribeau, 1993). Mempresentasikan pemikiran kita bukanlah proses yang sederhana. Apakah seseorang melihat diri kita seperti adanya? Mungkin tidak. Untuk itulah untuk memahami bagaimana gambaran ini saling berhubungan, dibutuhkan konsep avowal dan ascription. Avowal: proses dimana individu menggambarkan diri, ascription: proses di mana orang lain memberikan atribut pada identitas individual. Inti dari perspektif komunikasi adalah pemikiran bahwa identitas diekspresikan secara komunikatif dalam simbol inti, label, dan norma. Simbol inti merupakan kepercayaan mendasar dan konsep utama yang membedakan identitas tertentu. Label adalah sebuah kategori simbol inti. Label merupakan istilah yang digunakan untuk mengacu pada aspek tertentu dari identitas milik kita dan orang lain. Norma adalah beberapa nilai-nilai dari 
tingkah laku yang berhubungan/berkaitan dengan identitas tertentu.

Perspektif kritis melihat identitas secara lebih dinamis, sebagai akibat dari konteks yang cukup jauh dari individu. Pembentukan identitas kontekstual: pembentukan identitas dengan melihat konteks sejarah, ekonomi, politik, dan wacana. Resisting ascribed identities: ketika seseorang dihadapkan pada berbagai wacana mengenai identitas, dia ditarik ke dalam dorongan sosial yang memunculkan wacana tersebut. Seseorang mungkin akan menolak posisi (identitas) yang mereka berikan dan mencoba mengambil identitas lain. Sifat dinamis identitas: dorongan sosial yang membangkitkan identitasidentitas tersebut tidak pernah stabil dan selalu berubah.

Penelitian ini akan dikaji melalui perspektif intepretif untuk menegasikan suatu ekspresi identitas yang muncul atas relasi yang terjalin antara ayah dengan anak pada iklan audio visual diakses melalui kanal youtube https://www.youtube.com/watch? $\mathrm{v}=\mathrm{QrLPtz}$ OmzSk oleh Grab Official. Iklan ini dirilis sejak bulan November 2017 secara resmi dan beredar serentak melalui berbagai media, mulai dari media konvensional seperti televisi hingga berbagai situs atau laman internet, disisipkan pada berbagai media permainan digital yang menjadi kegemaran remaja, hingga disuguhkan sebagai iklan pembuka sebelum memutar tayangan video pilihan youtube.

\section{PEMBAHASAN}

Iklan grab dengan tema "Luangkan waktu untuknya", merupakan iklan mini komersial, dimana iklan ini berdurasi sekitar 2 menit. Terdiri dari 2 pemain utama dan beberapa pemain pendukung. Iklan Grab dengan tema "Luangkan waktu untuknya" bercerita tentang kisah kehidupan di dalam keluarga, yakni antara ayah dan anak. Dalam awal cerita yang ditampilkan, diceritakan bahwa anak tersebut sedang dalam kondisi gelisah, dimana ia sedang mengalami kegelisahan dalam batin tentang hubungan yang dibangun dengan ayahnya.

Dulu, ketika ia kecil sang ayah berharap kelak putra kesayangannya ini dapat meneruskan kepandaian ayahnya untuk dapat bermain wayang. Oleh karena itu, ayahnya sedini mungkin mengajak bercengkarama bersama untuk menanamkan kecintaannya kepada budaya wayang. Kilas balik tersebut menyeruak dalam suatu kegelisahan yang muncul secara tiba-tiba, karena kini keduanya tinggal terpisahkan oleh jarak. Hubungan jarak jauh antara ayah dan anak inipun hanya terhubung melalui surat yang dikirim berulang- ulang. Akhirnya berawal dari kerinduan mendalam untuk pulang kembali sekaligus nostalgia akan permainan wayang mendorong kuat bagi putra tersebut untuk segera kembali pulang menjumpai sang ayah. Upaya yang perlu direngkuh guna menjangkau rumah yang telah ia tinggalkan ditempuh menggunakan transportasi online, dimana Grab dipilih sebagai transportasi yang paling efektif agar segera sampai ke lokasi dan bertemu dengan ayahnya.

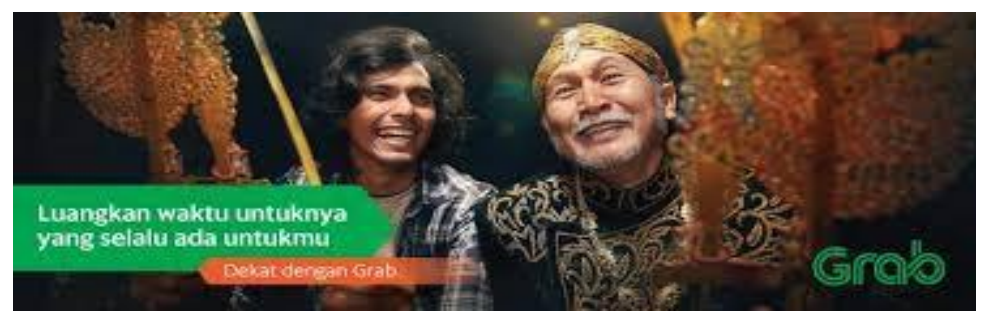

Gambar 1. Poster Iklan Grab Official

Sumber: https://www.facebook.com/GrabID/ 
Terdapat balutan nilai-nilai budaya yang menjadi kaijan utama sebagaimana nuansa utama iklan ini ditayangkan, dimana ulasan secara lebih mendalam terkait iklan tersebut dibahas melalui dimensi nilai budaya Hofstede, maka akan dihasilkan beberapa cakupan berikut: (1) Individualism vs Collectivism, (2) Power Distance, (3)
Masculinitiy vs Feminimity, (4) Uncertainty Avoidance, (5) Long Term vs Short Term Orientation, (6) Indulgence vs Restraint. Upaya peneliti mengurai berbagai dimensi tersebut ditempuh melalui deskripsi setiap adegan iklan Official Grab bertajuk "Luangkan Waktu Untuknya yang Selalu Ada Untukmu!" ini.

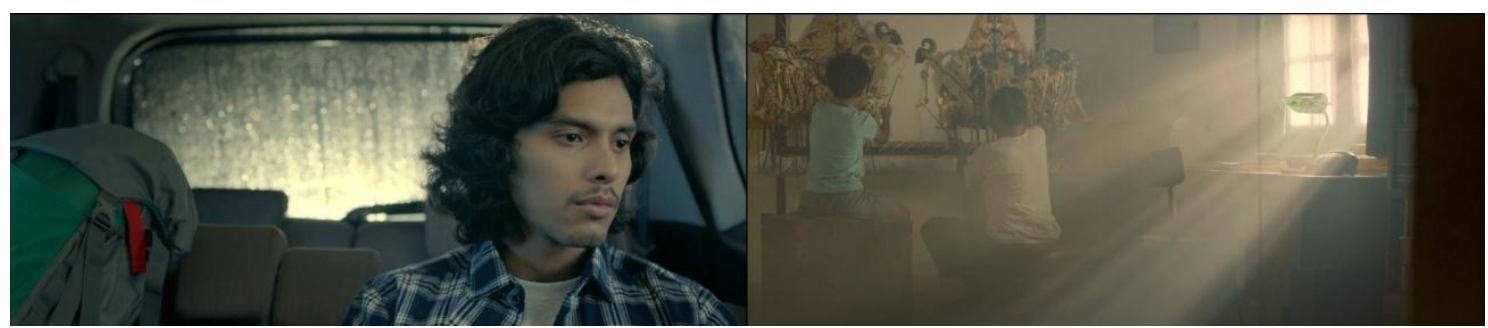

Gambar 2. Adegan Perdana shot 00:02 dan shot 00:09 Sumber: https://www.youtube.com/watch?v=QrLPtz0mzSk

Adegan awal 00:02 Gambar.2 dibuka dengan menampilkan sosok remaja pria yang nampak sedang memikirkan sesuatu di masa silam. Seolah-olah terdapat suatu hal yang tertinggal dan terpikir kembali seketika, kemudian dilanjutkan dengan potongan gambar berikutnya pada shot 00:09 yang memunculkan memori tersebut. Tampak gambaran masa kecil remaja pria tersebut sedang asyik bermain wayang bersama sang ayahanda. Situasi ini menggambarkan hubungan kolektif sebuah keluarga dibanding kemandirian individualis sang anak, sebagaimana prinsip Individualism dalam dimensi budaya Hofstede. Selain itu prinsip feminimity juga nampak, dari upaya menggugah emosi yang dibangun sang kreator iklan menghembuskan nuansa feminimitas. Demikian pula long term orientation, dimana arah iklan ini mempertimbangkan logika waktu lampau dan sekarang. Khalayak pun diajak melalui lorong waktu yang panjang seiring masa hidup pelaku utama iklan, yaitu semenjak usia belajar di masa kecil hingga usia remaja dewasa.

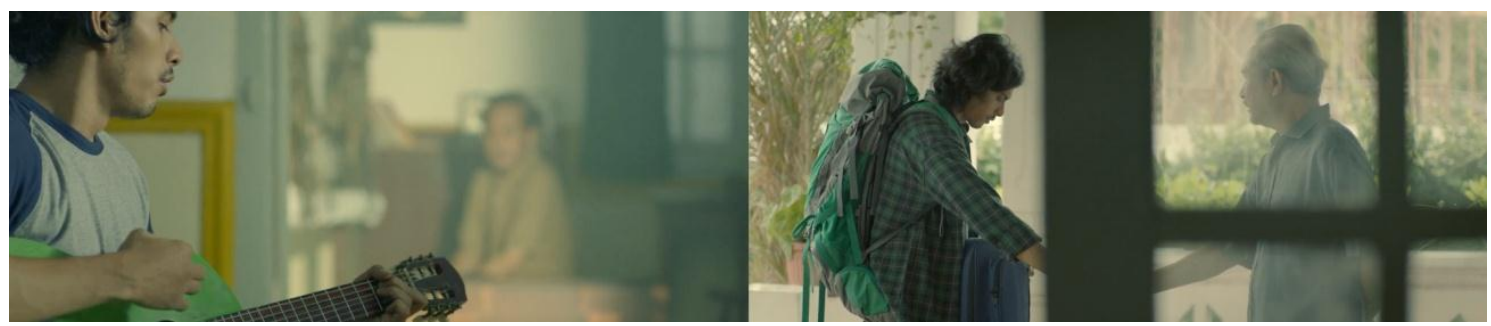

Gambar 3. Adegan Kedua shot 00:22 dan shot 00:27 Sumber: https://www.youtube.com/watch?v=QrLPtz0mzSk

Pada Gambar.3 dikisahkan anak yang ketika kecil diajarkan mengenal tradisi wayang sebagai salah satu budaya yang warisan khas Indonesia, kemudian beranjak dewasa hingga menemukan kegemarannya sendiri dengan alat gitar. Tampak bahwa remaja pria tersebut mulai meninggalkan kebiasaan memainkan wayangnya, 
sementara potongan gambar shot 00:22 juga diperlihatkan sang ayah duduk termangu melihat keasyikan putranya bermain gitar daripada larut memainkan wayang seperti sedia kala. Selanjutnya dikisahkan sang anak yang telah beranjak remaja memutuskan untuk meninggalkan rumah dan tinggal terpisah dari orang tuanya. High power distance nampak jelas pada potongan-potongan Gambar.3 shot 00:27 ini, dimana sang anak lebih memilih untuk tidak berkonfrontasi secara langsung dalam menyatakan tidak setuju maupun sikap tidak patuh ditunjukkan dengan menunduk sembari bersalaman. Selain itu, cara sang anak merepresentasikan bahwa dia dalam kondisi gelisah menandakan bahwa ada pola yang dibangun oleh keluarga mereka ketika mereka bekerjasama dalam meraih sebuah tujuan.

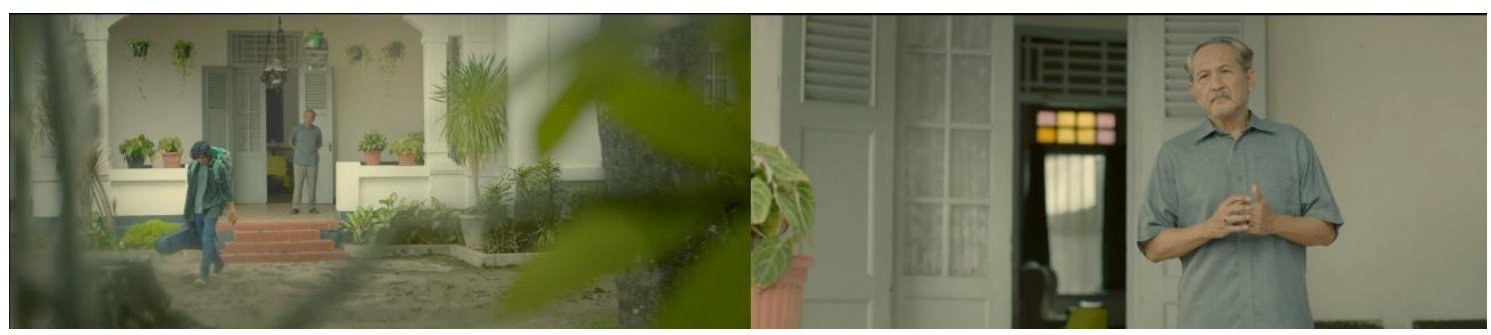

Gambar 4. Adegan Ketiga shot 00:27 dan shot 00:31 Sumber: https://www.youtube.com/watch?v=QrLPtz0mzSk

Dalam Gambar 1, 2, 3, dan 4 ini, tokoh utama dalam iklan digambarkan sebagai seorang anak. Secara pribadi dia tengah dihadapkan pada pencarian eksistensi dirinya, ketika berhadapan dengan realitas sosialnya terkait hal yang ada dalam lingkungan keluarganya. Atribut yang melekat hingga budaya yang dibangun oleh keluarganya, termasuk kebiasaankebiasaan yang dibangun oleh rumah tangga merupakan bagian yang tak terpisahkan dalam kehidupan anak tersebut. Secara personal dia adalah bagian dari elemen keluarga. Inilah kolektivitas di dalam keluarga yang meskipun sebagai satu kesatuan, ia merupakan bagian yang tidak terpisahkan. Demikian juga anak selalu memiliki hubungan dengan bagian lain dalam kelompok tersebut. Anak memiliki hubungan dengan anggota lainnya.

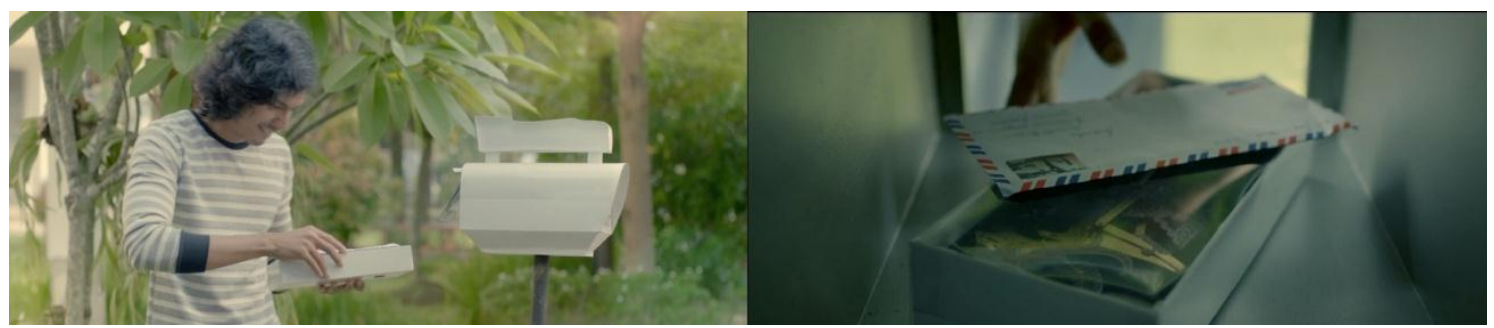

Gambar 5. Adegan Keempat shot 00:35 dan shot 00:45

Sumber: https://www.youtube.com/watch?v=QrLPtz0mzSk

Potongan adegan pada Gambar.5 ini tampak jelas ada keterkaitan ciri yang mengatas namakan feminimitas ketika menelaah iklan dari nuansa emosional maupun perhatian yang ditunjukkan para aktor. Dari gambar yang diambil, tampak seorang remaja yang tengah menilai hidupnya. Selepas sang remaja pria menjalani hidup di tengah hiruk pikuk perkotaan guna memenuhi ambisi 
pribadinya. Justru pilihan hidupnya menyimpang jauh dari jalan yang dipersiapkan sang ayah, bahkan ia berusaha mencoba keluar dari budaya yang selama ini menghidupi dan membesarkannya. Dikisahkan lebih lanjut bahwa upaya menghadapi perasaan gelisah serta rindunya diupayakan melalui sepucuk surat dan sekotak buah tangan berisi wayang. Gambar.4 nampak sebagai bagian dari High Uncertainty Avoidance yang dilakukan sang ayah kepada anaknya, memastikan "tali asih budaya" yang telah ditinggalkan dapat terus diingat sebagai warisan yang tidak boleh lekang oleh waktu. Di sisi lain, kondisi ini justru merefleksikan ekspresi dimensi budaya maskulinitas, karena tidak ada upaya saling menemui dan bentuk komunikasi yang disampaikan cenderung bersifat satu arah dari sang ayah kepada anaknya dan muncul upaya pengekangan atau restraint daripada indulgence.

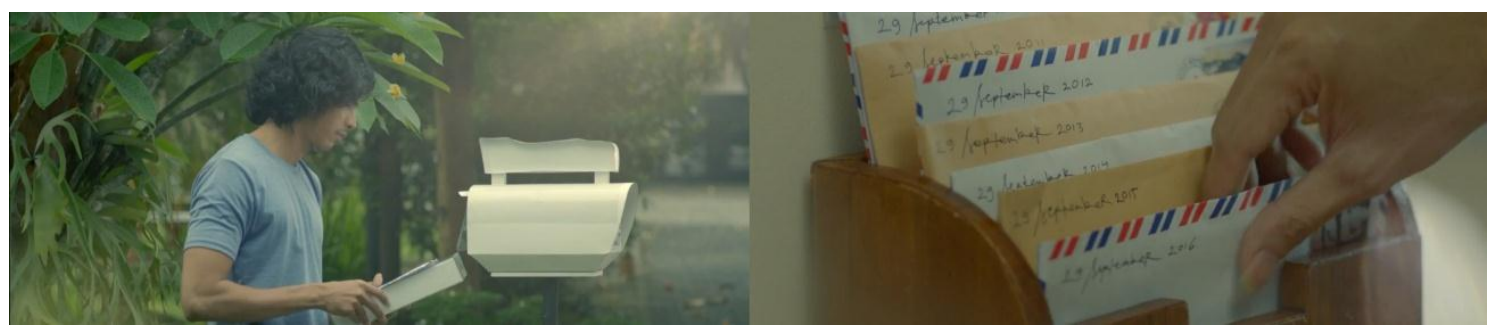

Gambar 6. Adegan Kelima shot 00:46 dan shot 00:50

Sumber: https://www.youtube.com/watch?v=QrLPtz0mzSk

Tidak ada satupun adegan yang memperlihatkan umpan balik sang anak kepada ayahnya, adegan kelima pada Gambar.6 shot 00:46 menunjukkan raut muka kurang menyenangkan dari sang anak ketika memperoleh surat ayahnya untuk kesekian kalinya, bahkan shot 00:50 nampak surat hanya dijajarkan saja secara rapi tanpa dibaca terlebih dahulu. Selain dimensi budaya maskulin (masculinity), nampak pula sifat individualis (individualism) dan cenderung abai terhadap upaya mengurangi ketidakpastian (low uncertainty avoidance). Kondisi anomali ini berkebalikan dengan tiga dimensi budaya Hofstede yang telah ditemukan peneliti pada potongan gambar 1-5 melalui adegan-adegan sebelumnya, yaitu: feminimity, colectivism, dan high uncertainty

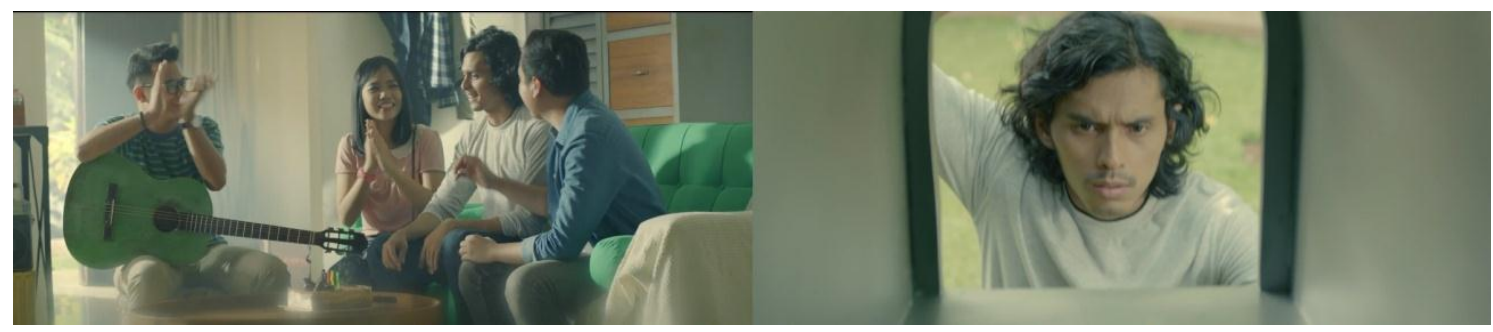

Gambar 7. Adegan Keenam shot 00:57 dan shot 01:01

Sumber: https://www.youtube.com/watch?v=QrLPtz0mzSk

Kondisi kembali berbalik pada adegan keenam Gambar.7 shot 00:57, dimana sang anak mulai merasa nyaman dengan lingkungan pertemanannya dan menunjukkan sifat kolektivis dimana dalam bertindak, anak tersebut membutuhkan dukungan yang besar dari teman-temannya. Sebaliknya keinginannya untuk kembali ke 
rumah sebagai tempat, dimana ia belajar banyak tentang budaya yang dialami dalam kurun waktu tertentu. Ditambah lagi pada shot 01:01 muncul kerinduan pada surat yang kerap kali dikirimkan oleh sang ayah, yang kini tidak pernah hadir di kotak suratnya. Ekspresi budaya terhadap identitas melalui relasi antara sang ayah dengan anaknya dapat ditelisik melalui dimensi budaya feminimitas (feminimity), ditambah lagi dengan tingginya suatu upaya meredam ketidakpastian (high uncertainty avoidance). Betapapun budaya yang telah lama ditinggalkan, namun ayahnya selalu menjadi sumber inspirasi dalam anak tersebut berkarya.

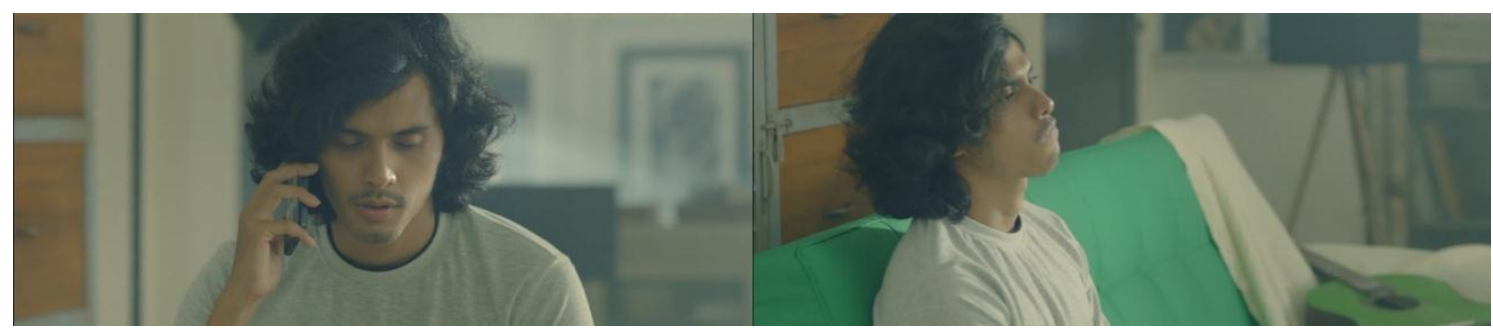

Gambar 8. Adegan Ketujuh shot 01:06 dan shot 01:08 Sumber: https://www.youtube.com/watch?v=QrLPtz0mzSk

Pada cuplikan ini, dituturkan bagaimana seorang anak akhirnya berusa menjalin komunikasi kembali dengan ayahnya. Anak tersebut ingin berkomunikasi dengan bapaknya yang adalah figur yang sangat berarti dalam hidupnya. Adanya dimensi low uncertainty avoidance pada Gambar 5 dan 6 secara lugas menerangkan adanya komunikasi dalam bentuk toleransi yang dibangun berdasarkan alur cerita tersebut adalah terjadi dalam tingkat kecemasan yang tinggi, sang anak terlambat dalam memberikan respon sehingga pola hubungan yang dibangun belum mampu memecahkan ketidakpastian. Artinya bahwa mereka masih mengupayakan sebuah komunikasi secara tidak langsung dengan memakai media surat sebagai perantaranya. Sang ayah selalu berusaha untuk berada pada posisi membangun komunikasi yang sehat dengan anaknya, meski sang anak kini sudah tidak bersamanya. Di tengah kesibukan dan kegiatan yang dilakukannya, mereka tidak melupakan adanya komunikasi.

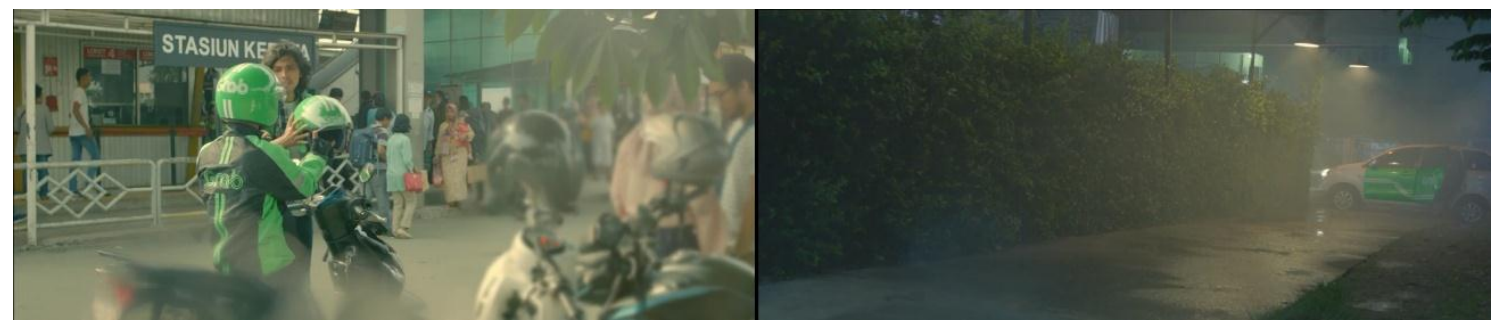

Gambar 9. Adegan Kedelapan shot 01:13 dan shot 01:20 Sumber: https://www.youtube.com/watch?v=QrLPtz0mzSk

Laju transportasi online dengan label Grab dipilih sebagai salah satu moda transportasi terkini yang menjadi preferensi utama di Indonesia (Utomo, 2017:1717).
Pilihan ojek online Grabbike dipilih anak tersebut untuk membelah kemacetan ibu kota sembari meninggalkan domisili sementara menuju stasiun. Perjalanan 
menggunakan kereta selanjutnya disambung dengan taksi online Grabcar dalam cuaca hujan deras menuju ke rumah ayahnya. Pada ulasan Gambar.9 shot 01:13 dan 01:20 ini, nampak bahwa dimanapun dan dalam kegiatan apapun relasi yang dibangun antara sang ayah dengan anaknya senantiasa terjaga untuk orientasi jangka panjang. Nilai yang diacu terkait dengan masa lalu dan sekarang, termasuk upaya menciptakan keharmonisan sebagai kestabilan, kemudian ditunjang dengan penghormatan pada tradisi budaya, hingga memenuhi kewajiban-kewajiban sosial sebagaimana peran ayah maupun sebagai anak. Hal ini tampak jelas ketika mereka tetap membangun kebiasaan lainnya seperti mengirim surat, dan melakukan kontak telepon. Tindakan- tindakan ini dilakukan untuk terus menghangatkan, membiasakan dan membudayakan jalinan relasi diantara mereka. Serta relasi- relasi lainnya, yakni komunikasi yang tiada hentinya. Mengirim miniatur wayang, menjadi salah satu sarana mengukuhkan identitas dari relasi diadik di antara keduanya.

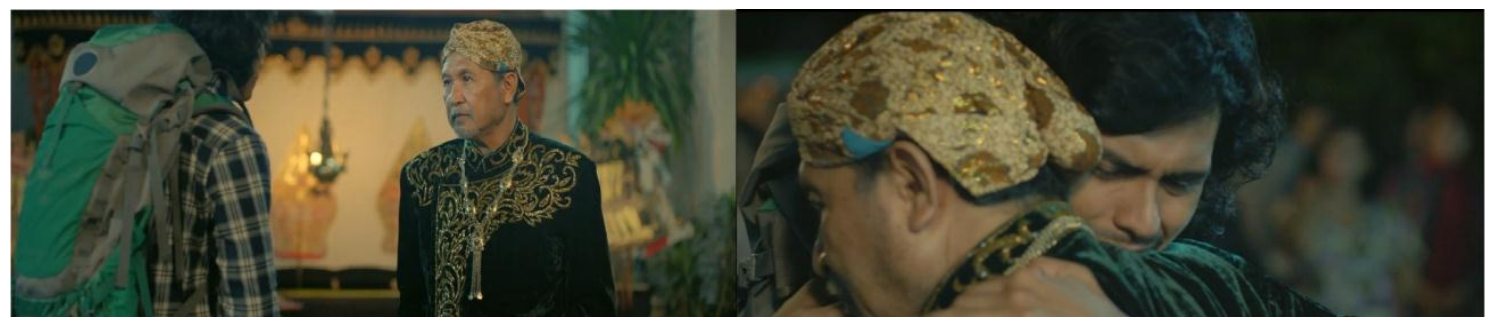

Gambar 10. Adegan Kesembilan shot 01:38 dan shot 01:46 Sumber: https://www.youtube.com/watch?v=QrLPtz0mzSk

Relasi diadik antara ayah dan anak pada iklan Grab Official ini semakin memuncak dan mencapai klimaksnya pada adegan kesembilan potongan Gambar.10 ini, dimana sang anak akhirnya bisa kembali berkumpul dengan ayahnya. Potongan shot 01:38 memperlihatkan antara raut kecewa sekaligus rindu akan perjumpaan yang senantiasa terjadi antara keduanya, dimensi budaya feminimity, colectivism, dan high uncertainty avoidance kembali mewarnai situasi ini. Posisi keduanya semakin erat pada potongan shot 01:57 yang memperlihatkan penyesalan sang anak bercampur kebahagiaan mendalam atas pertemuan kembali mereka. Kondisi ini merefleksikan adanya indulgence berkebalikan dengan restraint yang muncul sebelumnya, dimana mengarah kepada upaya lingkungan sosial yang mengijinkan bentuk gratifikasi sebagai nafsu manusiawi yang alamiah terkait dengan menikmati hidup kesehariannya. Baik di pihak sang ayah menjalankan kegemarannya dalam memainkan wayang rutinitasnya, sementara anaknya asyik beraktifitas bersama gitar kesayangan dan bergumul dengan teman-temannya.

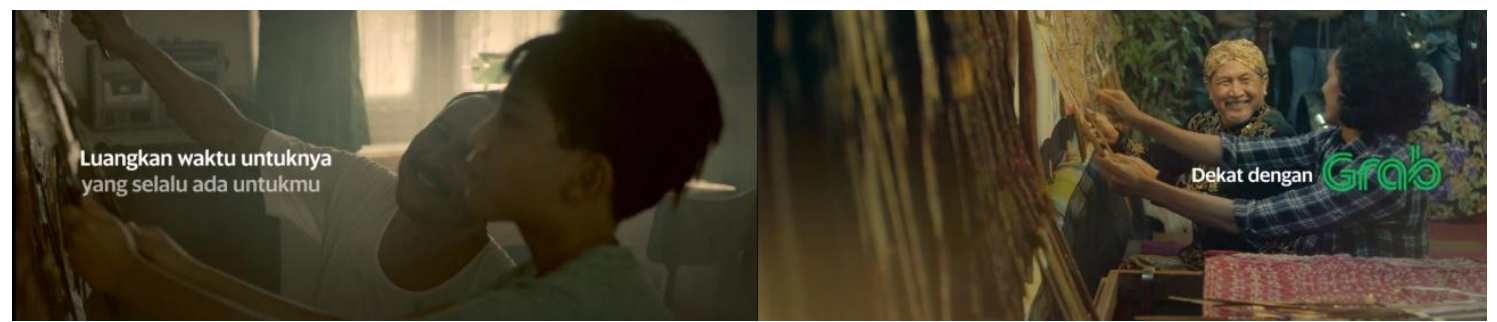

Gambar 11. Adegan Kesepuluh shot 01:54 dan shot 01:57

Sumber: https://www.youtube.com/watch?v=QrLPtz0mzSk 
Pada adegan terakhir ini khususnya potongan Gambar.11 shot 01:54, sang anak akhirnya dapat mengulang kembali kisah lama antara keduanya merayakan kebersamaan atas waktu berharga yang diluangkan bagi seseorang yang selama ini selalu menghadirkan diri satu sama lain. Potongan adegan ini berusaha mengingatkan pentingnya meluangkan waktu berharga bagi setiap orang yang tercinta, utamanya atas keberadaan mereka yang turut mengisi hari-hari kita. Pendekatan dimensi feminimitas (feminimity) ini ditempuh sebagai bentuk penyadaran akan kekuatan emosi yang memperkecil kesenjangan jarak kekuasaan (high power distance). Pada adegan kesepuluh potongan shot 01:57 memperlihatkan betapa peran Grab dalam mendekatkan relasi antara ayah dengan anak menjadi bersifat low power distance, hal ini merefleksikan ekspresi identitas budaya yang muncul. Situasi yang sebelumnya pernah menukik tajam sebagai konsekuensi atas keputusan sang anak berpisah setelah menentukan jalan hidupnya, kini berbalik menjadi suasana kehangatan kekeluargaan.

\section{SIMPULAN}

Interpretasi peneliti melalui dimensi nilai budaya Hofstede pada potongan gambar di sepuluh adegan iklan Official Grab bertajuk "Luangkan Waktu Untuknya yang Selalu Ada Untukmu!" ini dapat disimpulkan menjadi beberapa temuan umum. Dua dimensi utama yang menjadi "urat nadi" iklan ini, antara lain: dimensi orientasi waktu jangka panjang (long term orientation) dan kesenjangan jarak kekuasaan (high power distance). Konsistensi ditemukan sejak adegan perdana (Gambar.2) hingga adegan kesepuluh (Gambar.11), dimana terdapat jarak antar pelaku komunikan dan rentang periode waktu yang dihadirkan mencakup masa lampau hingga masa kini. Temuan ini sejalan dengan hasil riset Hofstede Insight (https://www.hofstede- insights.com/product/compare-countries/), dimana dua dimensi tersebut mendominasi dan kerap kali terjadi sebagai dimensi budaya yang memiliki prosentase di atas 50\% (High Power Distance $=78 \%$ dan Long Term Orientation $=62 \%$ ).

Empat dimensi budaya lain ditampilkan secara dinamis dalam beberapa potongan gambar di adegan-adegan tertentu, seperti contohnya adegan kelima yang ditunjukkan pada Gambar.6 adegan kelima shot 00:46 dan shot 00:50 memperlihatkan ekspresi dimensi budaya maskulin (masculinity), nampak pula sifat individualis (individualism) dan cenderung abai terhadap upaya mengurangi ketidakpastian (low uncertainty avoidance). Hal ini bertolak belakang dengan dimensi budaya feminim pada Gambar.1-4 adegan pertama hingga ketiga, dimana dimensi budaya yang muncul justru sebaliknya (feminimity, colectivism, dan high uncertainty avoidance). Selain itu pada Gambar.5 adegan keempat shot 00:35 dan shot 00:35 menunjukkan ekspresi dimensi budaya maskulinitas, karena tidak ada upaya saling menemui dan bentuk komunikasi yang disampaikan cenderung bersifat satu arah dari sang ayah kepada anaknya dan muncul upaya pengekangan atau restraint daripada indulgence. Temuan ini sangat bertolak belakang dengan Gambar.10 adegan kesembilan shot 01:38 dan shot 01:46, dimana dimensi budaya feminimity, colectivism, high uncertainty avoidance, dan indulgence kembali mewarnai situasi adegan yang memperlihatkan eratnya relasi diadik antara ayah dan anak semakin membuncah.

Kohesivitas di dalam komunikasi keluarga. Khususnya relasi diadik antara sang ayah dengan putranya yang direfleksikan melalui iklan Grab Official ini merepresentasikan budaya Indonesia. Hal ini tentu saja tidak muncul begitu saja tanpa adanya riset mendalam sebelumnya, jika bersandarkan pada simulasi dimensi budaya Hofstede Insight yang berpijak pada budaya Negara maka iklan "Luangkan Waktu Untuknya yang Selalu Ada Untukmu!" ini seutuhnya berupa konstruksi realitas budaya 
Nusantara. Meski tidak dapat digeneralisir, namun kategorisasi riset menjembatani keabsahan analisis data dengan memadukan pada prinsip kontinuitas sebagaimana yang diungkapkan oleh Agustiono (2017:297) dalam upaya mengoptimalisasi penyuntingan gambar gerak. Selanjutnya tentu saja iklan yang dikemas sedemikian rupa agar berkesan ini diharapkan mampu menimbulkan word of mouth hingga memicu intensi pembelian sebagaimana yang ditemukan dalam penelitian Widjaja (2016:241) pada upaya penyedia jasa transportasi online GoJek. Penelitian ini hanya bersifat representatif dengan memakai iklan sebagai media untuk menganalisa, maka dapat dikatakan subjek kajian tidaklah mendalam dan menyeluruh, perlu adanya penelitian mendalam yang bersifat eksploratif secara komprehensif untuk hasil yang jauh maksimal.

\section{DAFTAR PUSTAKA}

Aditya, Vita, Lisdian Fitri Nasrianti. 2017. Komunikasi Krisis di Sosial Media: Analisis Manajemen Krisis Iklan \#PilihAman Grab Bike Indonesia. Prosiding Seminar Nasional Komunikasi Publik dan Dinamika Masyarakat Lokal Magister Ilmu Komunikasi Universitas Lampung Buku B. November 2016 diakses dari

http://jurnal.fisip.unila.ac.id/index.p $\mathrm{hp} /$ prosidingmikom/article/view/34 8/250 pada 10 September 2018

Agustiono, Tri, Dwi Nurrahmi Kusmastuti, Suparwoto. 2017. Teknik Editing dengan Mengoptimalkan Kontinuitas Gambar dalam Produksi Features "Boyolali Tersenyum" dalam Akrab: Jurnal Komunikasi Vol.2(2) diakses dari https://ojs.akrb.ac.id/index.php/akra b/article/download/50/26 pada 12 Septermber 2018
Chang, Kara and Hao-Chieh Chang. 2014. Advertising to Chinese Youth: A Study of Public Service Ads in Hong Kong dalam Qualitative Market Research: An International Journal Vol.16(4) diakses dari https://repository.hkbu.edu.hk/cgi/v iewcontent.cgi?article $=1062 \&$ conte $\mathrm{xt}=\mathrm{coms} \_j a_{\text {pada }} 10$ September 2018

Christian, Michael. 2017. Pengaruh UnsurUnsur Iklan Pajak: Hiburan, Informatif, dan Nilai Iklan. Jurnal Bricolage Vol.3(2) diakses dari https://journal.ubm.ac.id/index.php/ bricolage/article/view/936 pada 10 September 2018

Hariningsih, Endah. 2013. Internet Advertising sebagai Sarana Komunikasi Pemasaran Interaktif. Jurnal Bisnis, Manajemen, dan Administrasi Vol.1(2) diakses dari http://www.amaypk.ac.id/download /jurnal/Internet_Advertising_Sebag ai_Media_Komunikasi_Pemasaran _Interaktif.pdf pada 08 September 2018

Hofstede. G. 1980. Cultures Consequences International Diffrences in Work Related Values. Beverly Hills, CA: Sage

1994. Cultures and Organizations Software of the Mind. London: Herper-Collins Publisher

https://www.facebook.com/GrabID/ Diunduh 11 September 2018. Pukul 18.20 WIB

https://www.grab.com/id/blog/luangkanwaktu-untuknya-yang-selalu-adauntukmu/ Diunduh 08 September 2018. Pukul 18.20 WIB

https://www.hofstedeinsights.com/product/comparecountries/ Diunduh 12 September 2018. Pukul 01.12 WIB 
https://www.republika.co.id/berita/ekonomi /keuangan/17/08/02/ou2dir361organda-indonesia-kehilanganpotensi-pajak-rp-16-

triliun? source $=$ graboards.com Diunduh 08 September 2018. Pukul 08.18 WIB

https://www.youtube.com/watch?v=QrLPtz 0mzSk Diunduh 10 September 2018. Pukul 10.18 WIB

Kartika, Ayu Satya, A.A. Gede Agung Artha Kusuma. 2016. Peran Efektivitas Iklan dalam Memediasi Daya Tarik Iklan terhadap Brand Attitude pada Iklan Merek Aqua (Studi pada Konsumen Aqua) di Kota Denpasar. E-Jurnal Manajemen UNUD Vol.5(1) diakses dari https://www.google.com/url?sa=t\& $\mathrm{rct}=\mathrm{j} \& \mathrm{q}=\&$ esrc $=\mathrm{s} \&$ source $=$ web $\& \mathrm{~cd}$ $=9 \& \mathrm{cad}=$ rja $\&$ uact $=8 \& \mathrm{ved}=2 \mathrm{ahUK}$ Ewjj0sDVxK_dAhVLpI8KHY4OA MUQFjAIegQIAhAC\&url=https\% $3 \mathrm{~A} \% 2 \mathrm{~F} \% 2 \mathrm{Foj}$ s.unud.ac.id\%2Finde x.php $\% 2$ FManajemen $\% 2$ Farticle $\%$ 2Fview\%2F15792\%2F11532\&usg =AOvVaw376fp1GQf89v62rszyK Cdt pada 08 September 2018

Leksono, Rafael Billy, Herwin. 2017. Pengaruh Harga dan Promosi Grab terhadap Brand Image yang Mempengaruhi Keputusan Pembelian Konsumen Pengguna Transportasi Berbasis Online. Jurnal Riset Manajemen dan Bisnis (JRMB) Fakultas Ekonomi UNIAT Vol.2(3) diakses dari https://jrmb.ejournal-

feuniat.net/index.php/JRMB/article/ view/72/57 pada 10 September 2018

Manickavelan, Suganya. 2013. A Study on The Effect of Public Service Announcement in Television dalam ABHINAV: National Monthly Refereed Journal of Research Arts \& Education Vol.2(6) diakses dari http://abhinavjournal.com/images/ Arts_\&_Education/Jun13/3.pdf pada 10 September 2018
Putra, Algamar. 2017. Pengaruh Iklan dan Kepercayaan Merek Terhadap Minat Beli Konsumen (Studi Pada Texas Chicken Pekanbaru). Jurnal Online Mahasiswa FISIP Universitas Riau Vol.4(1) diakses dari

https://media.neliti.com/media/publ ications/133492-ID-pengaruhiklan-dan-kepercayaan-merekter.pdf pada 08 September 2018

Putra, Muhammad Alamsyah Try, Nataniel Dengen, Andi Syakir. 2017. Iklan Layanan Masyarakat tentang Bahaya Banjir berbasis Multimedia Animasi Motion Graphic. Prosiding Seminar Ilmu Komputer dan Teknologi Informasi Vol.2(1) diakses dari http://ejournals.unmul.ac.id/index.php/SA KTI/article/viewFile/238/pdf pada 10 September 2018

Singh, Krishna Pal and Anurag Singh. 2017. Public Service Advertising in India: An Evaluation through Literature. International Journal of Marketing \& Financial Management Vol.5(3) diakses dari https://arseam.com/sites/default/file s/published-

papers/p8i3v5ijmfm\%20FP-

$\% 2053-$

64\%20Krishna $\% 20 \mathrm{Pal} \% 20$ Singh $\%$

20Mar-2017.pdf pada 10

September 2018

Utomo, Heru, Eriq Muh. Adams Jonemaro, Mahardeka Tri Ananta. 2017. Perbandingan Usabilitas Aplikasi Taxi Online Android (Grab-Car dan Uber) menggunakan Unified Theory of Acceptance and Use of Technology (UTAUT). Jurnal Pengembangan Teknologi Informasi dan Ilmu Komputer Vol.1(12) diakses dari https://jptiik.ub.ac.id/index.php/jptiik/article/download/624/244/ pada 08 September 2018 
Widiantoro, Danu. 2015. Strategi Perancangan Poster pada Iklan Layanan Masyarakat Kampanye Menabung Air di Yogyakarta dalam Kreatif: Jurnal Desain Komunikasi Visual Vol.3(1) diakses dari

http://www.stsrdvisi.ac.id/jurnal/12 8 pada 10 September 2018
Widjaja, Andrew Tjenghar. 2016. Pengaruh Word of Mouth dan Electronic Word of Mouth terhadap Purchase Intention: Sebuah Studi Kasus mengenai Perilaku Konsumen terhadap Jasa Ojek Online GoJek . Jurnal Bisnis dan Manajemen Vol.53(12) diakses dari https://journal.untar.ac.id/index.php /bm/article/download/744/633 pada 10 September 2018 